Pak. j. sci. ind. res. Ser. B: biol. sci. 201558 (2) 65-71

\title{
Cadmium Tolerance and Bioremediation Potential of Bacteria Isolated from Soils Irrigated with Untreated Industrial Effluent
}

\author{
Rizwan Ahmad*, Muhammad Mahmood-ul-Hassan, Muhammad Yasin and Vishandas Suthor \\ Land Resources Research Institute, National Agricultural Research Centre, Islamabad 45500, Pakistan
}

(Received July 22, 2014; revised May 7, 2015; accepted May 13, 2015)

\begin{abstract}
The present study was aimed to investigate the $\mathrm{Cd}$ tolerance of bacteria isolated from municipal effluent irrigated soils. Thirty bacterial strains were isolated and screened for their $\mathrm{Cd}^{+}$tolerance by growing on nutrient agar plates amended with varying amount of $\mathrm{Cd}^{+}$. Out of them four bacteria $\left(\mathrm{GS}_{2}, \mathrm{GS}_{5}, \mathrm{GS}_{10}\right.$ and $\mathrm{GS}_{20}$ ) were found highly Cd tolerant $(600 \mathrm{ppm} \mathrm{Cd})$. The minimum inhibitory concentration of $\mathrm{Cd}^{+}$ was found $200 \mathrm{ppm}$. The isolates showed optimum growth at $30{ }^{\circ} \mathrm{C}$ and $\mathrm{pH} 7.5-8.5$. Growth curve study against different concentrations of $\mathrm{Cd}(0-600 \mathrm{ppm})$ revealed that $\mathrm{GS}_{2}$ was more tolerant among selected strains showing only $33 \%$ reduction in growth compared to $64 \%$ by $\mathrm{GS}_{5}$ and $77 \%$ by both $\mathrm{GS}_{10}$ and $\mathrm{GS}_{20}$ at $600 \mathrm{ppm} \mathrm{Cd}$. Inoculation of maize seeds with $\mathrm{Cd}$ tolerant bacteria for root elongation demonstrated up to 1.7 fold increase in root elongation (in the absence of $\mathrm{Cd}$ ) and up to 1.5 fold (in the presence of $50 \mathrm{ppm}$ Cd) compared to the un-inoculated plants. The results of the study revealed that the bacterial isolates exhibiting great $\mathrm{Cd}$ tolerance and growth promoting activity can be potential candidates for bioremediation of metal contaminated soils and wastewaters.
\end{abstract}

Keywords: soil contamination, Cd tolerance, tolerance index, bioremediation

\section{Introduction}

The contamination of the environment with toxic heavy metals is a serious problem because it is associated with heavy metal accumulation in the food chain which later has an impact towards human health (Hamzah et al., 2009). Municipal/industrial effluents contain considerable amounts of different metals as: chromium $(\mathrm{Cr})$, cadmium $(\mathrm{Cd})$, lead $(\mathrm{Pb})$, nickel $(\mathrm{Ni})$ and copper $(\mathrm{Cu})$ in various combinations depending upon their source and nature (Khan et al., 2013; Mahmood-ul-Hassan et al., 2012). Release of untreated municipal/industrial effluents to agricultural lands and water bodies is a common practice in big cities of developing countries like Pakistan (Khan et al., 2013; Mahmood-ul-Hassan et al., 2012). Its longterm application can adversely affect soil and ecosystem health, ultimately human health (Singh and Bhati, 2005). Contamination of soil with heavy metals negatively affects biodiversity and the activity of soil microbial communities (McGrath et al., 1995). Continuous application of untreated wastewater elevates the metal concentrations in surface soil to toxic levels. As soil is a rich habitat of all major groups of microorganisms (bacteria, actinomycetes, fungi and algae), long-term exposure of microorganism to high metal concentration develop the immunity in the

*Author for correspondence; E-mail: rizwan_narc@yahoo.co.in microorganisms (Akhtar et al., 2013; Ezzouhri et al., 2009).

Among metal pollutants of the surface soil, cadmium is one of the most toxic elements. Cadmium is used in industries like Ni-Cd battery manufacturing, electroplating, pigments manufacturing and stabilizers manufacturing. In plants, $\mathrm{Cd}$ affects nutrient uptake and homeostasis, inhibits root and shoot growth and frequently accumulated by agriculturally important crops (Sanita di Toppi and Gabrielli, 1999). Cadmium is the most dangerous heavy metal both to human and animal health as it is carcinogenic, embryo toxic, teratogenic and mutagenic (Hussain et al., 2006). Excess $\mathrm{Cd}$ can damage kidney and lungs (Dhaliwal and Kukal, 2005). It may cause hyperglycemia, reduced immune potency and anemia, due to its interference with iron metabolism (Bueno et al., 2008).

Several techniques (chemical and physical) are used for remediation of polluted soil and water. Chemical (precipitation and neutralisation) and physical (ion exchange, membrane separation and electro dialysis) techniques are applied to remove heavy metals from contaminated soils and waste water (Atkinson et al., 1998). Such techniques have disadvantages like unpredictable metal ion removal, high reagent requirements, destruction of beneficial micro fauna and generation of toxic sludge (Ciba et al.,1999). 
Biological approaches have been considered as an alternative remediation for heavy metal contamination (Khan et al., 2009). Recent advances have been made in understanding metal-microbe interaction and their application for bioremediation of metal contaminated soils (Chibuike and Obiora, 2014). Bioremediation is the use of microbes like fungi and bacteria for removal of heavy metals and have been successfully used (Congeevaram et al., 2007). The metal tolerant microorganisms are helpful to alter the chemical status of the metal ions and in turn metal ion mobility. They act through processes such as reduction, bioaccumulation, mobilisation and biotransformation (Khan et al., 2009). Bioremediation is an efficient strategy due to its low cost, high efficiency and eco-friendly nature. It can be applied without removing and transporting contaminated soils. As soil matrix is not disturbed, soil micro flora and fauna are preserved.

Bacterial surfaces have several types of functional groups that can react with dissolved metals. Bacteria are important microorganisms to be used for biosorption and bioaccumulation of metals and hence are an important factor in controlling the mobility and distribution of metals in contaminated soil and water (Burnett et al., 2007). Biosorption is removal of heavy metals using passive binding process of living and dead biomass while bioaccumulation is referred as metal uptake into the cell across the membrane using active cell metabolism (Kotrba et al., 2011). Considering the importance of bacteria in bioremediation, this study was designed to isolate indigenous bacteria from polluted sites and assess their cadmium tolerance potential to use in bioremediation.

\section{Materials and Methods}

Samples collection. Six composite surface soil samples $(0-15 \mathrm{~cm})$ were collected from heavy metal polluted periurban areas of Gujranwala and Sialkot, Pakistan for this research work. Sampling sites have been continuously (more than 10 years) irrigated with untreated industrial/ municipal effluent with high metal contents. The surface soil samples were collected in sterilised plastic bottles and were transported to Soil Environment Laboratory, NARC, Islamabad, Pakistan in sealed containers. These containers were stored at $4{ }^{\circ} \mathrm{C}$ to ensure minimal biological activity till further process.

Isolation for cadmium tolerant bacteria. Dilution plate technique was used for isolation of microbes (Pepper and Gerba, 2004). Bacteria from soil were cultured with $10^{-4}-10^{-7}$ dilutions on nutrient agar medium at $28 \pm 2{ }^{\circ} \mathrm{C}$ for three days. Thirty prominent isolates (twenty from Gujranwala and ten from Sialkot sites) with some distinguished morphological characters (colony colour, size, shape etc.,) were further cultured and purified through repeated streaking on the same medium. The cultured strains were preserved on slants for $\mathrm{Cd}$ tolerance test at $4{ }^{\circ} \mathrm{C}$ and refreshed within three months regularly.

Minimum inhibitory concentrations (MIC) of Cd. To determine MIC for $\mathrm{Cd}$, the growth of isolated bacterial strains was tested on nutrient agar medium amended with ascending concentration of $\mathrm{Cd}$ starting from $50 \mathrm{ppm}$ (Kalantri, 2008). Stock solution (1000 ppm) of Cd salt $\left(\mathrm{CdCl}_{2}\right)$ was prepared with sterile water and added to the nutrient agar in varying concentrations (50-600 ppm). The process was continued with $50 \mathrm{ppm}$ interval till the growth was ceased. Highly tolerant strains (600 ppm Cd) were tested repeatedly for further confirmation.

Morphological and biochemical characterisation. For colony and cell morphology, bacterial strains were grown on nutrient agar medium at $28 \pm 2{ }^{\circ} \mathrm{C}$ for $36-48 \mathrm{~h}$. Each colony was characterised on the basis of colour, margin, elevation and cell shape with ocular and light microscopy. For gram staining, the slides of tolerant bacterial strains were prepared according to Benson (1994). A small loop of bacterial culture was taken and a thin smear on glass slides was prepared. The smear was air dried and heat fixed, stained with crystal violet stain for one minute and washed with water. Then the smear was flooded with iodine solution for $30 \mathrm{sec}$. After $30 \mathrm{sec}$ it was washed with water and smear was decolourised with $75 \%$ ethanol for $30 \mathrm{sec}$. After washing, safranin was used for counter staining. The slide was rewashed with water, air dried and observed under light microscope.

Indole acetic acid (plant hormone) production of $\mathrm{Cd}$ tolerant bacterial strains was detected by using the method stated by Brick et al. (1991). Bacterial cultures were grown in $250 \mathrm{~mL}$ conical flasks containing $50 \mathrm{~mL}$ nutrient broth (Lab-lemco powder 1.0; Yeast extract 2.0; Peptone 5.0; Sodium chloride 5.0, each was on $\mathrm{g} / \mathrm{L}$ basis) for 3 days at $28 \pm 2{ }^{\circ} \mathrm{C}$. Flasks were inoculated with different bacterial strains individually. Fully grown cultures were centrifuged at $3000 \mathrm{rpm}$ for $30 \mathrm{~min}$. The supernatant $(2 \mathrm{~mL})$ was mixed with two drops of orthophosphoric acid and $4 \mathrm{~mL}$ of the Salkowski reagent $(50 \mathrm{~mL}, 35 \%$ of perchloric acid, $1 \mathrm{~mL} 0.5 \mathrm{M} \mathrm{FeCl}_{3}$ solution). Development of pink colour indicates IAA production.

For measurement of phosphate solubilising activity, a single colony of each strain culture was streaked on 
Pikovskaya's medium containing tricalcium phosphate (EL-Komy, 2005) and incubated at $28 \pm 2{ }^{\circ} \mathrm{C}$ for 3 days. Qualitative determination was done by optically observing clear P-zone (halo-zone) formation around the colonies.

Screening for acid producing ability was determined by using the bromothymol blue indicator along with nutrient broth. Each strain was grown in $250 \mathrm{~mL}$ conical flasks containing $50 \mathrm{~mL}$ nutrient broth for 3 days at $28 \pm 2{ }^{\circ} \mathrm{C}$. Traces of bromothymol blue indicator were added to each flask at the time of inoculation. Dark green colour appeared at neutral $\mathrm{pH}$. Appearance of bluish green colour indicated the acid producing ability of the bacterial strain (Dupree and Wilcox, 1977).

Determination of optimum growth conditions. For optimum growth of bacterial isolates, two parameters i.e. $\mathrm{pH}$ and temperature were considered. To determine optimum $\mathrm{pH}, 30 \mathrm{~mL}$ test tubes having $10 \mathrm{~mL}$ nutrient broth were prepared in 5 sets for $\mathrm{pH}$ 6.0, 7.0, 8.0, 9.0 and 10 (each containing three test tubes) and autoclaved. These tubes were inoculated with freshly prepared culture of each isolate one by one. The tubes were incubated at $28 \pm 2{ }^{\circ} \mathrm{C}$ and $70 \mathrm{rpm}$. After an incubation period of $24 \mathrm{~h}$, their absorbance was taken at $600 \mathrm{~nm}$ wavelength on Spectronic Genesys 5 (Milton Roy Company, USA) and then a graph was plotted between $\mathrm{pH}$ (along x-axis) and absorbance (along y-axis).

For determination of optimum temperature, test tubes having $10 \mathrm{~mL}$ nutrient broth were prepared in 3 sets for 20,30 , and $40^{\circ} \mathrm{C}$. The $\mathrm{pH}$ of all the sets, each containing three test tubes was adjusted at 7 by using diluted $\mathrm{HCl}$ or $\mathrm{NaOH}$ solutions. Test tubes were autoclaved and then inoculated with freshly prepared cultures of different isolates individually. The tubes were incubated at 20 , 30 , and $40{ }^{\circ} \mathrm{C}$, respectively, with $70 \mathrm{rpm}$. After an incubation period of $24 \mathrm{~h}$, their absorbance was taken at $600 \mathrm{~nm}$ wavelength and then graph was plotted between temperature (along x-axis) and absorbance (along y-axis).

Growth curve and metal tolerance index. Nutrient broth with increasing concentrations of Cd i.e. 200, 400, 600 ppm was prepared and autoclaved. A control ( 0 ppm Cd) was also made. Growth of the selected heavy metal tolerant strains was studied at standard temperature $\left(30^{\circ} \mathrm{C}\right)$ and $\mathrm{pH}$ (7). Test tubes were inoculated and incubated for $24 \mathrm{~h}$ in water bath shaker at $70 \mathrm{rpm}$. After an incubation period of $24 \mathrm{~h}$, their absorbance was taken at $600 \mathrm{~nm}$ wavelength and then a graph was plotted between $\mathrm{Cd}$ concentration (along $\mathrm{x}$-axis) and absorbance (along $\mathrm{y}$-axis).
Metal Tolerance Index $\left(\mathrm{T}_{\mathrm{i}}\right)$ was calculated as the ratio of the optical density of the treated colony to that of the untreated colony.

$\mathrm{T}_{\mathrm{i}}=\frac{\mathrm{OD}_{\mathrm{t}}}{\mathrm{OD}_{\mathrm{u}}}$

Where:

$\mathrm{OD}_{\mathrm{t}}=$ optical density of treated colony and

$\mathrm{OD}_{\mathrm{u}}=$ optical density of the untreated colony.

Root elongation assay on filter paper culture. The plant root elongation promoting activity of the isolated bacteria was determined using the modified root elongation assay of Belimov et al. (2005). The seeds of maize variety ISD-gold were surface sterilised with a mixture of ethanol and $30 \% \mathrm{H}_{2} \mathrm{O}_{2}(1: 1)$ for $20 \mathrm{~min}$, washed with sterile water and placed on wetted filter paper. Bacteria were grown in nutrient broth for $48 \mathrm{~h}$ at $28 \pm 2{ }^{\circ} \mathrm{C}$. Bacterial suspensions $5 \mathrm{~mL}$ or sterile water (un-inoculated control) were added to petri dishes containing filter papers, both in the presence and absence of $50 \mathrm{mg} / \mathrm{L} \mathrm{Cd}$. Root length of seedlings was measured after incubation of closed petri dishes for 7 days at $28 \pm 2{ }^{\circ} \mathrm{C}$ in the dark. The assay was repeated twice with three dishes with 10 seeds per dish for each treatment.

\section{Results and Discussion}

Total heavy metals in Gujranwala and Sialkot soils. Surface soil samples used in this study were collected from peri-urban area of Gujranwala and Sialkot being irrigated with untreated wastewater (Table 1). The wastewater was a mixture of cottage industries and domestic effluent. Soil organic matter content was 0.7$2.0 \%$. The soils were alkaline in reaction $(\mathrm{pH}$ from 7.0 to 8.5 ), non-saline (electrical conductivity from 0.3 to $1.2 \mathrm{dS} / \mathrm{m}$ ) and calcareous in nature (lime contents from 1.5 to $15.2 \%$ ). The concentrations of different metals in soil of the study areas were; $\mathrm{Cd}$ ranged from 2 to 8.4 $\mathrm{mg} / \mathrm{kg}$; $\mathrm{Cu} 60$ to $380 \mathrm{mg} / \mathrm{kg} ; \mathrm{Pb} 205$ to $250 \mathrm{mg} / \mathrm{kg} ; \mathrm{Cr}$ $80-330 \mathrm{mg} / \mathrm{kg}$ and $\mathrm{Ni}$ from 90 to $130 \mathrm{mg} / \mathrm{kg}$. The total soil $\mathrm{Cd}, \mathrm{Cu}, \mathrm{Cr}, \mathrm{Pb}$ and $\mathrm{Ni}$ content in almost all the soil samples were higher than the permissible limits, i.e., 3, $100,100,100$ and $50 \mathrm{mg} / \mathrm{kg}$, respectively, as proposed by FAO/WHO (2001). Heavy accumulation of these metals in the soils are results of their use in different industries like ceramics, sanitary fittings, electrical and gas appliances, detergent manufacturing, dry batteries, plastic-ware, kitchen-ware and tanneries. The elevated concentrations of heavy metals in the soils are most likely due to long-term continuous application of 
Table 1. Geographical position of peri-urban sites of sample collection

\begin{tabular}{|c|c|c|c|}
\hline Site & City & North & East \\
\hline 1 & Gujranwala & $32^{\circ} 06^{\prime}$ & $74^{\circ} 10^{\prime}$ \\
\hline 2 & Gujranwala & $32^{\circ} 07^{\prime}$ & $74^{\circ} 10^{\prime}$ \\
\hline 3 & Gujranwala & $32^{\circ} 07^{\prime}$ & $74^{\circ} 11^{\prime}$ \\
\hline 4 & Gujranwala & $32^{\circ} 09^{\prime}$ & $74^{\circ} 11^{\prime}$ \\
\hline 5 & Sialkot & $32^{\circ} 28^{\prime}$ & $74^{\circ} 30^{\prime}$ \\
\hline 6 & Sialkot & $32^{\circ} 29^{\prime}$ & $74^{\circ} 32^{\prime}$ \\
\hline
\end{tabular}

untreated municipal/ industrial effluent containing these heavy metals.

Screening and characterisation of $\mathrm{Cd}$ tolerant bacterial strains. In this study, a total of 30 soil bacteria were isolated from the heavy metal contaminated soils. Minimum inhibitory concentration of Cd was found 200 ppm. Similar results were also reported by Ansari and Malik (2007), who reported MIC of 200 ppm for Cd. Out of 30, 21 bacterial strains tolerated cadmium (Cd) up to $200 \mathrm{ppm}$, thirteen strains were moderately tolerant (400 ppm Cd) and only 4 strains $\left(\mathrm{GS}_{2}, \mathrm{GS}_{5}, \mathrm{GS}_{10}\right.$ and $\left.\mathrm{GS}_{20}\right)$ were found highly tolerant (600 ppm Cd).

The selected 4 bacteria were characterised morphologically and bacteria were also observed under microscope for cell shape (Table 2). Most of the strains had phosphorus solublisation and acid producing activity with bacillus cell shape and gram negative staining. None of the tolerant strain had IAA producing ability in the absence of L-tryptophan. IAA producing ability in the presence of L-tryptophan was not studied.

Results have shown that microorganisms in a contaminated environment could have adapted to that environment over a period of time. Piotrowska-Seget et al. (2005) also found in his study that, prolonged exposure of soil bacteria to $\mathrm{Cd}$ can develop resistance to its toxicity by activating the tolerance mechanism towards $\mathrm{Cd}$. Most of the bacteria they studied were gram negative.

Optimum growth conditions, growth curve and tolerance index. The effect of $\mathrm{pH}$ on the growth of selected 4 bacterial isolates is shown in Fig. 1 and the effect of temperature is shown in Fig. 2. Optimum $\mathrm{pH}$ varied from 7.5 to 8.5 which was in accordance with the $\mathrm{pH}$ of the soils from which the strains were isolated (Mahmood-ul-Hassan et al., 2012). Regarding temperature, optimum growth of bacterial isolates was found at $30^{\circ} \mathrm{C} \pm 2$. It shows that the selected bacteria are well adapted to soil as well as the climatic conditions of the regions from where they were isolated and can be reused in field conditions of the same ecology.

Growth curves of 4 highly Cd tolerant bacterial strains were made against different concentrations of $\mathrm{Cd}$ ranging from 0 to 600 ppm (Fig. 3). It is obvious from the result that at low concentration of $\mathrm{Cd}(200 \mathrm{ppm})$ the bacterial growth was high as compared to control; however, at 400 and $600 \mathrm{ppm} \mathrm{Cd}$, the growth of all bacterial strains was also suppressed.

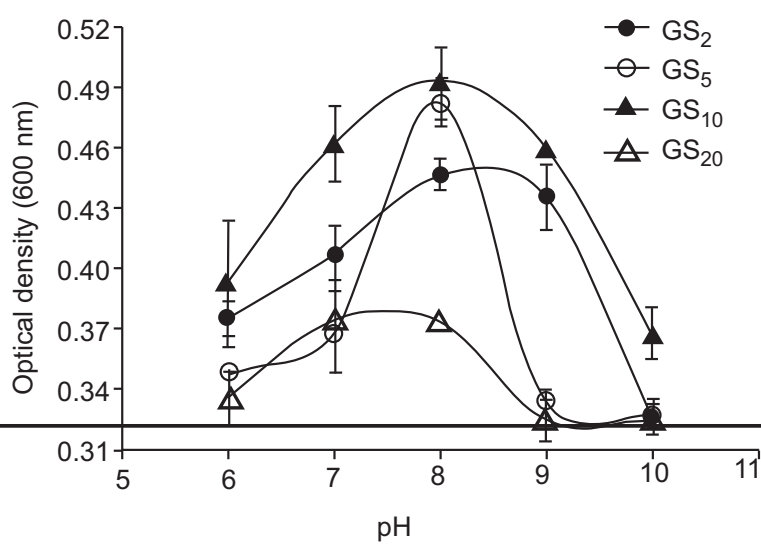

Fig. 1. Growth of Cd-tolerant bacteria as affected by different $\mathrm{pH}$ at $30^{\circ} \mathrm{C}(\mathrm{N}=3)$.

Table 2. Morphological, biochemical and microscopic characteristics of Cd-resistant bacterial strains

\begin{tabular}{|c|c|c|c|c|}
\hline \multirow[b]{2}{*}{ Characteristics } & \multicolumn{4}{|c|}{ Bacterial strain } \\
\hline & $\mathrm{GS}_{2}$ & $\mathrm{GS}_{5}$ & $\mathrm{GS}_{10}$ & $\mathrm{GS}_{20}$ \\
\hline Colony shape & Filamentous & Filamentous & Filamentous & Irregular \\
\hline Colony colour & Yellowish white & White & Yellowish white & Creamy \\
\hline Elevation & Umbonate & Concave at centre & Concave at centre & Umbonate \\
\hline Margin & Undulate & Lobate & Erose & Undulate \\
\hline Cell shape & Bacillus & Bacillus & Coccus & Bacillus \\
\hline Gram staining & - & - & - & - \\
\hline P-solublising & + & - & + & + \\
\hline Acid production & + & - & + & + \\
\hline IAA-production & - & - & - & - \\
\hline
\end{tabular}




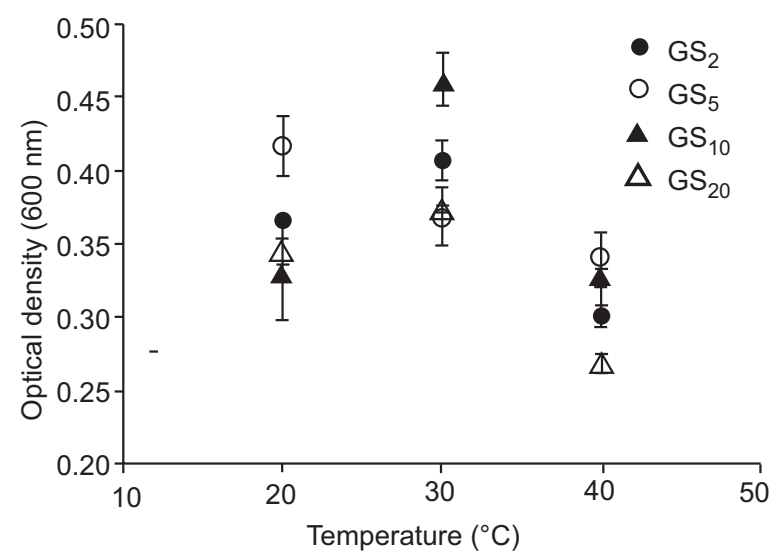

Fig. 2. Growth of Cd-tolerant bacteria as affected by different temperatures at $\mathrm{pH} 7(\mathrm{~N}=3)$.

At 200 ppm Cd, optical density of $\mathrm{GS}_{2}, \mathrm{GS}_{10}$ and $\mathrm{GS}_{20}$ showed an increase of 30, 12 and 13\%, respectively, over control $(0 \mathrm{ppm} \mathrm{Cd})$. However, there was $7 \%$ reduction in case of $\mathrm{GS}_{5}$. The results show that except $\mathrm{GS}_{5}$ all other bacterial strains have so much adapted to $\mathrm{Cd}$ that they have bio-accumulated it to some extent. At $400 \mathrm{ppm} \mathrm{Cd}$, growth of all the bacterial strains was reduced. $\mathrm{GS}_{2}$ was found more tolerant with $10 \%$ reduction in growth and $\mathrm{GS}_{5}$ least tolerant with $64 \%$ reduction. Reduction of growth in case of $\mathrm{GS}_{10}$ and $\mathrm{GS}_{20}$ was 35 and $55 \%$, respectively, (Fig. 3).

Contrary to other bacterial strains, $\mathrm{GS}_{2}$ again was found more tolerant at $600 \mathrm{ppm} \mathrm{Cd}$ with $33 \%$ reduction in growth. The growth of $\mathrm{GS}_{5}$ at 400 and 600 ppm Cd was almost similar (64\% reduction); however there was a sharper decrease in the tolerance indices of $\mathrm{GS}_{10}$ and $\mathrm{GS}_{20}$ at 600 ppm than at $400 \mathrm{ppm}$. There was up to $77 \%$ decrease in the growth of $\mathrm{GS}_{10}$ and $\mathrm{GS}_{20}$ at 600 ppm Cd (Fig. 3).

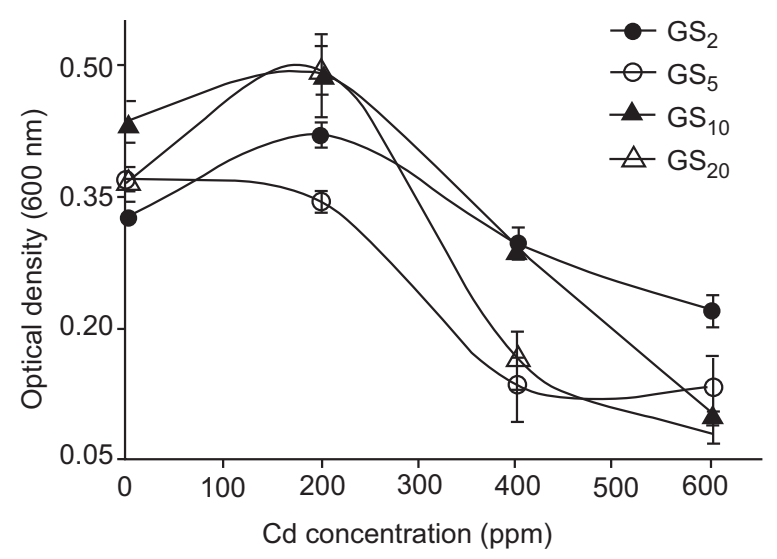

Fig. 3. Growth curve of Cd-tolerant bacteria as affected by different concentration of $\mathrm{Cd}$ at $\mathrm{pH}$ and temperature $30^{\circ} \mathrm{C}(\mathrm{N}=3)$.
Cadmium tolerance indices of all tested bacterial strains at different $\mathrm{Cd}$ concentrations are presented in Fig. 4. $\mathrm{GS}_{2}$ being more tolerant among all strains showed highest tolerant index at highest concentration of $600 \mathrm{Cd}$. Tolerant indices of other bacterial strains revealed the order of tolerance as; $\mathrm{GS}_{5}>\mathrm{GS}_{10}>\mathrm{GS}_{20}$.

Findings of other researchers also revealed that, $\mathrm{Cd}$ has inhibitory effect on bacterial growth (Kalantri, 2008; Laddaga and Silver, 1985). Higher Cd concentration can reduce the activities of essential enzymes such as protease, urease, arylsulphatase and alkaline phosphatase (Lorenz et al., 2006).

Root length promotion. The effects of $4 \mathrm{Cd}$-resistant bacterial strains on root elongation of maize variety ISD-gold in the absence of $\mathrm{Cd}$ is shown in Table 3. Addition of $50 \mathrm{mg} / \mathrm{L} \mathrm{Cd}$ to the filter paper culture inhibited root elongation of un-inoculated seedlings by $33 \%$. Inoculations with Cd-resistant bacteria in the absence and presence of $\mathrm{Cd}$ significantly increased the root length of maize seedlings over un-inoculated seedlings. The maximum root length promoting effect on Cd-treated plants was observed after inoculation with strains $\mathrm{GS}_{2}$ (150\% over control). It was followed by $\mathrm{GS}_{10}$ and $\mathrm{GS}_{20}$; both produced $130 \%$ increase over control. The minimum increase in root length where seeds were treated with $\mathrm{Cd}$ was observed after inoculation with strains $\mathrm{GS}_{5}(78 \%)$. Statistically similar trend was observed where seeds were inoculated in the absence of $\mathrm{Cd}$.

Sheng and Xia (2006) and Belimove et al. (2005) also observed root growth promotion of Indian mustard inoculated with $\mathrm{Cd}$ resistant bacteria over un-inoculated seedlings in the presence of $\mathrm{Cd}$. Rhizobacteria belonging

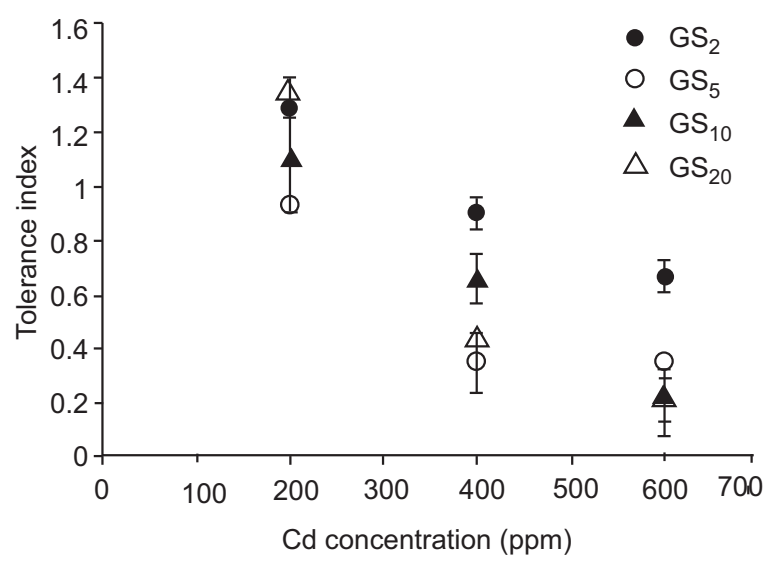

Fig. 4. Tolerance index of Cd-tolerant bacteria as affected by different concentration of $\mathrm{Cd}$ $(\mathrm{N}=3)$. 
Table 3. Root length of maize seedlings inoculated with Cd-resistant bacterial strains grown in absence or presence of $\mathrm{Cd}$ in nutrient solution $(\mathrm{N}=3)$

\begin{tabular}{|c|c|c|c|c|}
\hline \multirow[t]{2}{*}{ Bacterial strains } & \multicolumn{2}{|c|}{ Untreated seedlings } & \multicolumn{2}{|c|}{ Treated with $50 \mathrm{mg} / \mathrm{L} \mathrm{Cd}$} \\
\hline & $\begin{array}{l}\text { Root length } \\
(\mathrm{mm})\end{array}$ & $\begin{array}{l}\text { Bacterial effect } \\
(\%)\end{array}$ & $\begin{array}{l}\text { Root length } \\
(\mathrm{mm})\end{array}$ & $\begin{array}{l}\text { Bacterial effect } \\
(\%)\end{array}$ \\
\hline Uninoculated control & $33.0^{\mathrm{e}}$ & - & $22.4^{\mathrm{d}}$ & - \\
\hline $\mathrm{GS}_{2}$ & $92.1^{\mathrm{a}}$ & +176.6 & $56.0^{\mathrm{a}}$ & +150.0 \\
\hline $\mathrm{GS}_{5}$ & $54.5^{\mathrm{d}}$ & +63.7 & $40.0^{\mathrm{c}}$ & +78.6 \\
\hline $\mathrm{GS}_{10}$ & $63.0^{\mathrm{b}}$ & +89.2 & $51.5^{\mathrm{b}}$ & +129.9 \\
\hline $\mathrm{GS}_{20}$ & $59.8^{\mathrm{c}}$ & +79.6 & $51.5^{\mathrm{b}}$ & +129.9 \\
\hline LSD & 3.3 & - & 2.7 & - \\
\hline
\end{tabular}

to different genera such as Pseudomonas, Mycobacterium, Agro-bacterium and Arthrobacter were found to have plant growth-promoting characteristics that can potentially support heavy metal uptake and reduce stress symptoms in plants (Dell'Amico et al., 2005). He et al., (2009) observed an increase in root growth and Cd contents in above ground tissues of hyperaccumulator tomato grown in Cd conta-minated soil when inoculated with two metalresistant bacteria; Pseudomonas sp. and Bacillus sp. Both the bacteria were indole acetic acid and aminocyclopropane1-carboxylate deaminase producers. Thus proliferation of root growth in metal contaminated soil either by presence of indole acetic acid or aminocyclopropane-1-carboxylate deaminase enzyme could lead to enhanced uptake of heavy metals in hyperaccumulator plants which could help in bioremediation.

\section{Conclusion}

Bacteria isolated from heavy metal-contaminated peri urban areas of Gujranwala have the ability to tolerate higher concentrations of $\mathrm{Cd}$. Cadmium resistance potential and root growth promoting activity of these isolates demonstrated that, these bacteria could be used as a potential candidate in the bioremediation of $\mathrm{Cd}$ contaminated wastewater and soil.

\section{Acknowledgement}

The research work was financially supported by the Pakistan Agricultural Research Council through the 'Research for Agricultural Development Programme'; We thank Ghulam Haider, Riaz Ahmad and Ishfaq Ahmad for assistance in laboratory and field work.

\section{References}

Akhtar, S., Mahmood-ul-Hassan, M., Ahmad, R., Suthor, V., Yasin, M. 2013. Metal tolerance potential of filamentous fungi isolated from soils irrigated with untreated municipal effluents. Soil \& Environment, 32: 55-62.

Ansari, M.I., Malik, A. 2007. Biosorption of nickel and cadmium by metal resistant bacterial isolates from agricultural soil irrigated with industrial wastewater. Bioresource Technology, 98: 3149-3153.

Atkinson, B.W., Bux, F., Kasan, H.C. 1998. Considerations for application of biosorption technology to remediate metal-contaminated industrial effluents. Water Safety, 24: 129-35.

Belimov, A.A., Hontzeas, N., Safronova, V.I., Demchinskaya, S.V., Piluzza, G., Bullitta, S., Glick, B.R. 2005. Cadmium-tolerant plant growth-promoting bacteria associated with the roots of Indian mustard (Brassica juncea L. Czern.). Soil Biology and Biochemistry, 37: 241-250.

Benson, H.J. 1994. Microbiological Applications. Laboratory Manual in General Microbiology. W.C. Brown Publishers, Dubuque.

Brick, J. M., Bostock, R.M., Silverstone, S.E. 1991. Rapid in situ assay for indole acetic acid production by bacteria immobilized on nitrocellulose membrane. Applied and Environmental Microbiology, 57: 535-538.

Bueno, B.Y.M., Torem, M.L., Molina, F., de Mesquita, L.M.S. 2008. Biosorption of lead (II), chromium (III) and copper(II) by R. opacus: Equilibrium and kinetic studies. Mineral Engineering, 21: 65-75.

Burnett, P.G., Handley, K., Peak, D., Daughney, C.J. 2007. Divalent metal adsorption by the thermophile Anoxybacillus flavithermus in single and multi-metal systems. Chemistry and Geology, 244: 493-506.

Chibuike, G.U., Obiora, S.C. 2014. Heavy metal polluted soils: Effect on plants and bioremediation methods. Applied and Environmental Soil Science, 2014: 1-12.

Ciba, J., Kolewicz, T., Turek, M. 1999. The occurrence of metals in composted municipal wastes and their removal. Water Air and Soil Pollution, 111: 159-170. 
Congeevaram, S., Dhanarani, S., Park, J., Dexilin, M., Thamaraiselvi, K. 2007. Biosorption of chromium and nickel by heavy metal resistant fungal and bacterial isolates. Journal of Hazardous Material, 146: 270-277.

Dell'Amico, E., Cavalca, L., Andreoni, V. 2005. Analysis of rhizobacterial communities in perennial Graminaceae from polluted water meadow soil, and screening of metal-resistant, potentially plant growth-promoting bacteria. FEMS Microbiology Ecology, 52: 153-162.

Dhaliwal, G.S., Kukal, S.S. 2005. Essentials of Environmental Science. 369 pp., Kalyani Publishers, New Delhi, India.

Dupree, M.R., Wilcox, G. 1977. Bromothymol blue and carbohydrate sensitive plating media. Journal of Clinical Microbiology, 6: 343-347.

El-komy, H.M. A. 2005. Coimmobilization of Azospirillum lipoferum and Bacillus megaterium for successful phosphorus and nitrogen nutrition of wheat plants. Food Technology and Biotechnology, 43: 19-27.

Ezzouhri, L., Castro, E., Moya, M., Espinola, F., Lairini, K. 2009. Heavy metal tolerance of filamentous fungi isolated from polluted sites in Tangier, Morocco. African Journal of Microbiology Research, 3: 35-48.

FAO/WHO, 2001. Codex alimentarius commission. Food additives and contaminants. Joint FAO/WHO Food Standards Program 2001. FAO Viale delle Terme di Caracalla, Rome, Italy.

Hamzah, W.N., Arifin, W.M., Khoo, K.S., Lee, L.J. Sarmani, S.B. 2009. Screening of biosorption bacteria tolerance towards copper and cadmium from oil sludge pond. Journal of Radioanalytical and Nuclear Chemistry, 281: 295-298.

He, L.Y., Chen, Z.J., Ren, G.D., Zhang, Y.F., Qian, M., Sheng, X.F. 2009. Increased cadmium and lead uptake of a cadmium hyperaccumulator tomato by cadmiumresistant bacteria. Ecotoxicology and Environmental Safety, 72: 1343-1348.

Hussain, I. 2006. Investigation of heavy metals $\mathrm{Cu}, \mathrm{Pb}$, $\mathrm{Cd}, \mathrm{Mn}, \mathrm{Cr}, \mathrm{Fe}$ and $\mathrm{Ni}$ in Ammi visnaga. Journal of Chemical Society of Pakistan, 28: 241-245.

Kalantri, N. 2008. Evaluation of toxicity of iron, chromium and cadmium on Bacillus cereus growth. Iranian Journal of Basic Medical Sciences, 10: 222-228.
Khan, A., Javed, S., Muhmood, A., Majeed, T., Niaz, A., Majeed, A. 2013. Heavy metal status of soil and vegetables grown on peri urban area of Lahore district. Soil \& Environment, 32: 49-54.

Khan, M.S., Zaidi, A., Wani, P.A., Oves, M. 2009. Role of plant growth promoting rhizobacteria in the remediation of metal contaminated soils. Environmental Chemistry Letters, 7: 1-19.

Kotrba, P., Mackova, M., Macek, T. 2011. Microbial Biosorption of Metals. Springer, New York, USA.

Laddaga, R.A., Silver, S. 1985. Cadmium uptake in Escherichia coli K-12. Journal of Bacteriology, 162: 1100-1105.

Lorenz, N., Hintemann, T., Kramarewa, T., Katayama, A., Yasuta, T., Marschner, P., Kandeler, E. 2006. Response of microbial activity and microbial community composition in soils to longterm arsenic and cadmium exposure. Soil Biology and Biochemistry, 38: 1430-1437.

Mahmood-ul-Hassan, M., Suthar, V., Rafique, E., Ahmad, R., Yasin, M. 2012. Metal contamination of vegetables grown on soils irrigated with untreated municipal effluent. Bulletin of Environmental Contamination and Toxicology, 88: 204-209.

McGrath, S.P. 1995. Long term effects of metals in sewage on soils, microorganisms and plants. Journal of Industrial Microbiology, 14: 94-104.

Pepper, I.L., Gerba, C.P. 2004. Dilution and plating of bacteria and growth curves. In: Environmental Microbiology; A Laboratory Manual. pp. 3-10. Elsevier Academic Press, USA.

Piotrowska-Seget, Z., Cycon, M., Kozdroj, J. 2005. Metaltolerant bacteria occurring in heavily polluted soil and mine spoil. Applied Soil Ecology, 28: 237-246.

Sanita di Toppi, L., Gabrielli, R. 1999. Response to cadmium in higher plants. Environmental and Experimental Botany, 41: 105-130.

Singh, G., Bhati, M. 2005. Growth of Dalbergia sissoo in desert regions of western India using municipal effluent and the subsequent changes in soil and plant chemistry. Bioresource Technology, 9: 1019-1028.

Sheng, X.F., Xia, J.J. 2006. Improvement of rape (Brassica napus) plant growth and cadmium uptake by cadmiumresistant bacteria. Chemosphere, 64: 1036-1042. 